\title{
THE CONTINUATION COMMITTEE CONFERENCES IN INDIA
}

\section{THE PLAN AND METHOD}

Thоse who were most completely dominated by the spirit of the Edinburgh Missionary Conference were above all things anxious to see the visions of the assembly transformed into action at the earliest possible moment. That was the reason for the creation of the Continuation Committee.

But the Continuation Committee, with its subordinate committees, had scarcely begun its work when the members became conscious that, before serious action could be taken, it must obtain much fuller knowledge of the work of the mission field, and must secure to the utmost the co-operation of the workers on the field. The Committee therefore invited its chairman, Dr. John R. Mott, to undertake a journey to India, China, Korea and Japan, with this object in view, and Dr. Mott, after careful consideration, found it possible to undertake the task.

The plan adopted, after mature deliberation, was that Dr. Mott should hold a chain of some twenty conferences in the various sections of these great fields of the East, and that in each country, after the close of the sectional conferences, a national conference should be held, to gather up and co-ordinate results. It was proposed that each conference should consist of not more than some fifty persons, chosen with the extremest care from the area covered by the conference, so that not only the various missionary societies but the Indian Church and every type of work being carried on in the area should receive representation. It was believed that in small gatherings of 
this nature it would be possible to get at facts and convictions much more rapidly than in a large conference. Several friends in Britain, Canada, and the United States offered to bear the expenses of the journey and of the conferences, so that these might be without cost to the Continuation Committee, the missionary societies, or organizations on the field.

An outline of the plan was sent to India. At first, in almost every province, a good deal of hesitation and unwillingness was felt and expressed. Men were tired of conferences and felt that the duty of the hour was steady work and not talk. It had been decided to postpone the Decennial Conference, which, in the ordinary course of things, would have been held in 1912 : how, then, could any man propose to hold, not one, but seven conferences, that very year? Yet confidence in the Continuation Committee was so strong that a central committee was appointed in Calcutta and local committees in the other provinces, and most faithful and successful work was done in preparation for the campaign.

In personal consultation with representatives of the leading missionary societies in North America and Europe, and with the Special Committees of the Continuation Committee, and after correspondence with men in the mission field, Dr. Mott prepared a list of important questions on which light was wanted. This list was revised by the Continuation Committee and sent to the local committees in India for criticism and suggestion.

The following is the order in which the conferences in Ceylon and India were held: Colombo, Nov. 11 to 13; Madras, Nov. 18 to 20 ; Bombay, Nov. 25 to 27 ; Jubbulpore, Nov. 29 to Dec. 2 ; Allahabad, Dec. 3 to 6 ; Lahore, Dec. 9 to 11 ; Calcutta, Dec. 16 to 18 ; the National Conference, Dec. 18 to 21 . The conference in Burma followed early in January.

For each conference a room was secured of sufficient dimensions to make it possible that each delegate should 
be provided with a table. Dr. Mott presided. To his right there would sit the secretary of the local committee and the timekeeper of the conference with his bell. On the left a couple of Dr. Mott's helpers would be seated. At a table in front of the chairman sat the stenographer to take down a verbatim report of the proceedings. The delegates, each with his table, were set round as nearly as possible in semi-circular order. Maps, charts, and tables of statistics prepared by the local committee to illustrate the occupation of the province were hung on the walls. The proceedings were private; and, with the exception of a very few visitors representing mission boards and other Christian organizations at home, only delegates were admitted. Each delegate had before him a copy of the questions which had been suggested for discussion. These were drawn up under the following heads : The Occupation of the Field ; the Indian Church ; Indian Christian Leadership ; the Training of Missionaries; Christian Education; Christian Literature; Evangelization; Co-operation between Missions. Under each of these there was a considerable number of questions, far more than could be dealt with in the time available. Hence each conference appointed its own business committee to decide which of these questions should be taken up for discussion and how much time should be allotted to each.

The limited number of the delegates enabled each conference to become, from the very beginning, a hardworking, business-like committee, gathering information, comparing convictions and thinking out conclusions with wonderful rapidity and precision. Short speeches, single sentences, even monosyllabic answers, became the order of the day. In most of the conferences each speaker was limited to five minutes on each question; yet very seldom was any one hindered from adequate expression. The great majority of the speeches averaged from two to three minutes in length. In this way a very large number of voices were heard on every topic; every point of view 
was expressed; an extraordinary number of significant and poignant facts were elicited; and everything of the nature of apology or rhetoric or padding dropped out. We venture to think that a new type of deliberative assembly has been created, likely to prove of great value.

The conferences were in the fullest sense representative. Many interdenominational assemblies have met in India, but none comparable with these. All the missions, except those of the Roman Church, were represented. One expected to see the central group of societies which have always worked together present in full force ; but, besides these, practically every Lutheran mission, almost every group of high Church Anglicans, the Syrian Church of Travancore, the Salvation Army, and the leading indigenous missions of India were all represented. The leaders of the Indian and Ceylonese Churches took a prominent part in each conference. European laymen scarcely made their appearance, but there was no lack of capable Indian ar.ù Ceylonese laymen.

Each conference decided to express its convictions, so far as these were unanimous or practically unanimous, in a series of findings. A small sub-committee was appointed for this task in connexion with each group of questirns submitted for diccussion. These men watched the discussion very carefully, so as to be able to express as accurately as possible the mind of the conference, and then drew up the findings. The business committees held a special meeting at which these draft findings were most carefully dealt with; and they were then brought up before the full conference to be accepted, rejected, or amended.

The long agenda laid before each conference, the extraordinary interest of the questions proposed for discussion, the three brief days available for everything, and the time-limit set for speaking, combined to give each gathering a most serious and strenuous character. Every delegate looks back upon his conference as a time of severe strain, yet perhaps still more as a period of golden privilege 
and priceless work. No one left a conference as he entered it. New forces had come into his life, tresh light on the situation, a sense of divine urgency, a new hope, a consciousness of the vast resources which God has prepared for them that love Him.

Yet every one felt very keenly the pitiable incompleteness of the discussions. Each subject was little more than opened, and briefly touched on, when it had to be laid aside. In each conference this caused at first a good deal of disappointment; yet all recognized that it was inevitable ; and it bore within itself one vast advantage : every one felt that the work had barely been begun, and that it was imperative that means should be found to carry it on in the same serious spirit in which it had been started.

The devotional spirit was very marked throughout. Each day had its period set apart for intercession; but besides that every hour was filled with a spirit of prayer and aspiration. There was a happy social spirit abroad also. The frankness of the discussions astonished many, and, above all, the fact that such frankness could co-exist with such complete unity of spirit. In several of the conferences the Indian delegates helped matters forward very greatly by their outspokenness combined with brotherliness. Each conference opened rather quietly; enthusiasm rose gradually as men began to realize the new world opening before them; and the discussion of the findings lifted the exhilaration of the delegates to the height ; for in many cases these went much further than had ever been found possille before.

That which justifies the whole movement is the fact that every province decided to create an organization (or to modify an existing one) in order to carry forward and bring into actual being all that had been decided; and the whole will be crowned by a national organization. The Continuation Committee conferences clearly open a new era in Indian missions. 


\section{THE SIGNIFICANCE OF THE CONFERENCES AND THEIR CONCLUSIONS}

ThE series of conferences held in November and December last throughout India and Ceylon under the presidency of Dr. Mott mark a notable stage in the development of missionary work in India. Conferences of missionaries of different denominations are no novelty. They are held at different centres every year, and in many cities every month. The All-India Decennial Conference is now a well-established institution. But these conferences held by Dr. Mott have been unique in the forethought with which they have been planned and organized, in the thoroughness of their work, in the completeness of the arrangements made for eliciting and focussing the best thought and experience of the Indian field, and in the wise provision of an adequate machinery for making the findings of the Conference effective in the future.

The findings of the All-India Conference are of peculiar value. They sum up in the briefest possible space the deliberate opinion of the leading missionaries of India and Ceylon as to the points that need emphasis, the methods that should be adopted, the directions in which we ought to advance, the weak spots that need strengthening. They will be a stirring manifesto to the supporters of missions at the home base and an invaluable guide both to committees at home and the missionaries on the field.

The outstanding feature of the conferences as a whole was undoubtedly the spirit of unity and brotherhood which pervaded them. This was especially manifest in the final All-India Conference. It would, I think, have been difficult for any outsider, who might have come into the Conference without knowing its composition, to have guessed that it brought together the representatives of different denominations supposed to be antagonistic. Throughout all our work and discussions there was the 
deep underlying sense of a great common cause that united us all in the bonds of brotherhood. There was no effort needed to sink our differences. They did not emerge on the surface. I was not able to be present at the great conference in Edinburgh in 1910, but some of those who took part in it as well as in our Indian conferences told me that the spirit of unity in the latter was, if anything, intensified and raised to a higher level. And judging from the account of the debate at Edinburgh on the promotion of unity given by Mr. Gairdner in his book on Edinburgh 1910 , I think that this is true. In Edinburgh there was evidently a strain and tension which was markedly absent in India. One noticeable feature in our Indian conferences was the large number of Anglican bishops, as well as missionaries of both the S.P.G. and C.M.S., who took part in them. At Colombo, Madras, Bombay, Jubbulpore, Allahabad, Lahore and Calcutta the provincial conference was attended by the bishop of the diocese, while. at the national conference the Bishop of Lahore (soon to become Metropolitan of India), the Bishops of Madras and Chota Nagpur and the Rev. V. S. Azariah (soon to be consecrated as the first Indian bishop of the Anglican Church), were all present and took an active and prominent part in the work of the Conference. This is a distinct advance upon Edinburgh, where the Anglican bishops were few in number and felt constrained to adopt an attitude of apology and self-defence. In India no apology or self-defence was needed.

When we compare the findings of this conference with the resolutions of the last Decennial Conference held in 1902 we notice at once a striking advance in many directions.

(1) The most remarkable of the findings in this respect were those on the Indian Church and Indian Christian leadership. They are a calm and well-balanced statement of ideas that have long been in the air, but have never before been so clearly summed up or so emphatically endorsed by a representative body of missionaries in India. 
The desire on the part of many leaders of the Indian Christian community for a comprehensive Church; the demand that the Indian Church, while continuing to receive and absorb every good influence which the Church of the West may impart to it, yet in respect of forms and organization should have entire freedom to develop on such lines as will conduce most to the natural expression of the spiritual instincts of Indian Christians ; the recognition of widespread indications of a true spirit of sacrifice and service in the Indian Church, and the conviction that, whenever capable and spiritually minded men and women are discovered, Churches and missions should make a real and unmistakable advance by placing Indians on a footing of complete equality, in status and responsibility, with Europeans; the emphasis laid on the principle that the work carried on by foreign missionary societies should be gradually transferred, as opportunities offer, to the Indian Church, and the opinion expressed that in view of the importance of this principle all positions of responsibility made available for Indian Christians should be related to Church organizations rather than to those of foreign missionary societies;-these are views and opinions that have been often expressed and advocated at home and in the mission field. But the significant fact is that they have now been made part of a definite, well-considered programme, and deliberately adopted, after a careful and searching criticism of every phrase and word, by the most representative body of missionaries in India which it would be possible to assemble. It is hardly an exaggeration to say that this fact marks a definite change in the objective of our work. So far we have often talked and written about developing the Indian Church ; but the immediate, practical aim has been the strengthening and unifying of the individual mission. The Indian Church was, after all, only a dream of the future. This conference marks the fact that the Indian Church has now become a matter of practical politics. 
(2) An almost equally striking advance of opinion is seen in the findings on mass movements. The resolution of the Decennial Conference on the subject in 1902 was singularly meagre and uninspiring. The findings of the recent conference are a trumpet call to the Churches in India and at home to seize a magnificent opportunity and to press resolutely through an open door that may soon be closed. The points specially emphasized-that in many parts of India the depressed classes and aboriginal tribes, who number over fifty millions, are extraordinarily open to the message of the Gospel ; that there are strong influences at work tending to close the open door, and that, therefore, the claim upon the missionary societies to gather in this vast harvest is urgent and imperative-are again not new. They have been urged insistently by individual missionaries for the last twenty years. But the fact that they have now been endorsed by this representative conference will impress upon the Church in India and at home the imperative need of grappling with this gigantic task in right earnest, with tenfold force.

The evidence quoted at the conferences as to the results already achieved through these mass movements was very striking. It more than justified the emphatic statements on this point in the findings. The results are described as twofold. First, in the progress of the converts themselves: "Even where the converts have come from the lowest and most degraded section of society, already within the short space of fifty years large numbers of them have exhibited to a very remarkable degree the fruit of the Spirit, and have by their Christian lives won the respect of those who formerly despised and treated them as untouchable.' And second, in the influence of the movements upon the Christian Church and the Hindu community : 'The work among these classes,' it is said, 'is dealing a powerful blow at the caste spirit, which in some parts of the Church has had so fatal an influence in paralysing its missionary spirit, and also is a great witness to that law 
of God's kingdom by which $\mathrm{He}$ chooses the weak to confound the strong and the things that are not to bring to naught the things that are. It is a remarkable fact that wherever in the village districts the work among the depressed classes has been most successful, there the caste people have been most ready to hear and accept the message of the Gospel. It is noticeable, too, that no part of the Church's work in India excites more concern and emulation among many sections of the educated classes.'

This sums up briefly a mass of evidence from all parts of India as to the value and significance of these great movements and will set at rest the doubts that have been freely expressed by those who only know of these movements from the outside, lest the gathering in of so many thousands of poor, illiterate people from the lowest sections of Hindu society should fatally lower the moral standard of the Church and erect a fresh barrier against the conversion of the middle and educated classes. The opinion of the conference is emphatic: "These mass movements, if properly dealt with, will be of untold value to the cause of Christ in India.' But they must be properly dealt with. The conference emphasizes the fact that 'to gather in this harvest and to train and educate the converts, demand a far stronger and more widespread effort than has yet been made.' The immediate needs to be provided for and the methods to be adopted are briefly outlined under nine heads, which deserve careful study as embodying the practical experience of the missionaries engaged in dealing with the mass movements in all parts of India.

(3) The findings on co-operation and unity not only register the progress of opinion and sentiment on this great question, but initiate a policy. There is something almost startling in the calm, quiet language in which the conference, after recording its thankfulness to God for the spirit of Christian love and co-operation that has marked its proceedings, proceeds to give effect to the recommendations of the various provincial conferences with a 
view to promoting co-operation, by propounding a scheme for the establishment of provincial representative councils for missions and a national council for missions. To any one who remembers the state of things that existed thirty years ago, the matter-of-fact way in which this scheme of federal councils was introduced, accepted, embodied in the findings, and started without a note of dissent or protest or anxiety is most amazing. The scheme will be carefully scrutinized both at home and in the mission field, and possibly it may need many modifications in detail ; but the broad fact that councils of this kind have suddenly leapt into the sphere of practical politics is a fact of immense significance. They must necessarily lead to large measures of co-operation; they will render flagrant violations of comity almost impossible; they will make the experience of every large mission available for the whole of India ; they will enable the Christian army to concentrate its forces as it has never done before on strategic centres, and above all they will foster and intensify the spirit of unity and brotherhood.

(4) The findings on Christian education will, it is hoped, prove an end of strife. There has been a prolonged controversy for the last thirty or forty years over our educational policy, and education has come to be regarded in some quarters as the rival of mass movements and evangelization. The conference arranges terms of peace between the combatants and brings them together in a higher unity. It strikes the right note in the preamble, by drawing attention to the fact that the very large accessions, mostly from the depressed classes, have resulted in a marked diminution in the literacy of the Christian community as a whole, and that the success of our missionary activities imposes on us a heavy responsibility for the education of our members. There is, therefore, now 'a widespread demand for the extension of primary education throughout India, which in conjunction with the present accessibility of the depressed classes to missionary effort constitutes a 
call to the Church to provide as rapidly as may be a largely increased body of qualified teachers to enable it to seize this opportunity. Apart from all other considerations a vigorous educational policy is absolutely necessary to raise the converts from the depressed classes to a higher level of spiritual and moral life and to enable the Indian Church to take up the great task of the evangelization of India.'

The aim of mission schools and colleges is stated as threefold-the upbuilding of the Church through the training of the children and youth of the Christian community; the conversion of individual students; and the diffusion of Christian ideas as a preparation for the large influx of converts that we believe is coming into the Christian Church. Many educationalists in India will hail with great satisfaction the recommendations of the conference with a view to securing greater efficiency. All the recommendations are important and deserve careful attention. Many of us will specially rejoice at the statement 'that, since it is desirable to produce a profound Christian impression rather than a diffused Christian atmosphere, if the choice at any time should be between more students and more efficient education, the latter should be unhesitatingly chosen.' I believe myself that this goes straight to the source of the serious weakness of many of our mission schools and colleges. They have outgrown our resources. In some places there are perhaps too many of them, in others they are too large. The result in some institutions is a weak Christian staff, a small proportion of Christian students, a non-Christian atmosphere and a weak Christian influence. Efficiency and intensity are the two watchwords of the conference in the matter of education.

(5) Women's work, medical work and Christian literature were treated with a thoroughness which makes the findings on these subjects peculiarly valuable, and it is noticeable that the importance of the European and Anglo-Indian community in the missionary work of the Church was at 
last recognized though somewhat inadequately. It is well that a special committee has been appointed to gather information as to the relation of members of this community to the missionary cause. In the last Decennial Conference, and at Edinburgh, the importance of the Europeans and Anglo-Indians was entirely ignored, and yet their presence in India constitutes a fact to be reckoned with in the spread of the kingdom of God. They number altogether about 250,000 , and by reason of their wealth, position and influence stand to the people of India as witnesses for or against the gospel of Christ. At the same time they must form an important element in the Christian Church. The conference has done well to call attention to this much neglected subject.

Looking at the spirit that inspired the conferences as a whole, two things strike me as deserving special notice apart from the sense of unity and brotherhood which I have dwelt on above. First, there is the growth of a scientific temper and method in the mission work of the Church in India. Hitherto the work has been carried on very much by rule of thumb and at haphazard. There has been no settled plan of campaign. Missions have often been dumped down or have grown up through force of circumstances without any well-considered policy. The strength or weakness of a mission has often depended far more on the personality and influence of the missionary in charge than on the needs of the work. Then there has been too little effort made to avoid overlapping, to correlate missionary agerıies, to study methods of work and to educate the workers. But this conierence marks the dawn of a new day. Its findings are instinct with a scientific passion for information and efficiency. It wants to know the facts, study the conditions, compare methods, form plans, and have a definite policy. It proclaims that the old haphazard ways are obsolete. We are going for the future to survey India as a whole and to try to make each department of our work as perfect and complete as possible. 
Missions are becoming more and more what our American friends would call a business proposition.

And then, secondly, there was the inspiring spirit of hopefulness, based upon a quiet confidence in the will of God and the infinite power of His Holy Spirit. This is happily no new feature in missionary conferences, but it is good to feel that as the area of battle extends and the conflict becomes fiercer, the hope and thankfulness of the army of God grow stronger and deeper. As we look back on what God has done for us in the past we thank Him and take courage ; as we look forward to the future our hearts thrill with a great hope that the day is not far distant when we shall march as one united army against sin and falsehood, and by our unity convince all men that Jesus Christ is indeed the Son of God and the Saviour of the world.

Henry Madras

\section{THE BEARING OF THE CONFERENGES ON CO-OPERATION}

IT would perhaps be an exaggeration to say that these conferences have introduced a new era in the history of co-operative effort in Indian mission work, for that might seem on the one hand to ignore the fact that the spirit of unity has already found many notable expressions, and on the other to assume that the forces that make for isolation have now at last been overcome. Yet when every allowance has been made for the possibility of underrating the past or overrating the future, the fact remains that the missionary force, so far as it could be represented at the conferences, has taken a decided step forward, and even if for any cause the hopes that have been aroused should largely fail to be realized it is inconceivable that the failure should be so absolute as to leave us no further than we were before.

We are encouraged to cherish this expectation by a 
number of considerations of which the following are the chief. To begin with, the conferences were the most representative ever held in India. In the second place, the atmosphere which pervaded the conferences was wonderfully conducive to unity. Those who came together, though belonging to many countries and differing widely in their views of doctrine and polity as well as in opinion regarding the problems under discussion, were conscious of a strange oneness. It was clearly understood that no one who attended was expected to sacrifice any conviction, or be silent about any matter on which his opinions might differ from those of others. Yet in the presence of an overwhelming task people realized that in spite of all differences they were one, and it is hardly necessary to say that they were most conscious of their unity in those solemn periods of intercession, which came as interruptions to the business and were yet rightly regarded as the most serious part of each day's work. These days of fellowship in work and prayer made impressions that cannot be easily effaced.

The reports regarding the measure of comity and cooperation already existing were on the whole encouraging. The general testimony was to the effect that in such matters as territorial division, salaries of Indian workers, and the reception of agents or of members under discipline, a steady improvement was taking place, and that breaches of the spirit of comity were due rather to the inexperience or unwisdom of individuals than to the settled policy of any society. It was shown, too, that the spirit of co-operation, more especially in the conduct of educational institutions, was markedly on the increase. This development was in some cases due to the timely action of individuals, but had been greatly stimulated by such organizations as the missionary associations which existed in several provinces, and the missionary conferences of the larger centres. It was felt, however, that much remained to be done, and each conference set itself to find what the next step was so far as its area was concerned. 
It is significant that, as in the case of the Edinburgh Conference, the need of drawing closer was felt in connexion with almost every one of the topics discussed. Under the head of 'occupation,' for example, it was found in each area that there was still very much land to be possessed, and that on the other hand there was a certain amount of overlapping. It was accordingly resolved to go much further than had yet been done in the way of making a thorough survey of the field, and this of course could be done only by co-operative effort. In the matter of education, again, the need of combination, more especially in the higher education, was keenly felt, and in some cases definite plans were proposed. Approval was expressed of the work of the educational unions which exist in several provinces, and resolutions were passed in favour of strengthening existing unions or founding new ones where necessary. The limitations in the way of actual unification imposed by doctrinal differences were clearly recognized, more especially in the case of theological and, to a lesser extent, in that of normal training. But the feeling of the majority was that even these were not insuperable if provision were made by means of hostels for denominational fellowship and instruction. With regard to the training of missionaries the need of co-operation in the maintenance of language-study schools was recognized by all. Under 'evangelization' the holding of united missions was recommended, and of joint 'summer schools' for the workers. In the production and distribution of Christian literature the need for co-operation is too obvious to need mention. Several of the conferences expressed strong desires for the extension of the plan, already at work in the Tamil field, of having literature missionaries supported by the societies working in the area, and the national conference appointed a committee to endeavour to carry the unification of production, more especially of English works, much further than had hitherto been done.

In connexion with the subject of the Indian Church 
it was found that the desire for a national Church was far from being universal, being confined to the educated members of the Christian community and not universal among them. It was felt, however, that such an ideal should not be lost sight of, and the feeling of the great majority was gathered up in the finding of the national conference, which runs as follows :-

- Desire for a Comprehensive Church.-This Conference is of opinion that there is undoubtedly a strong desire on the part of many of the leaders of the Indian Christian community for a comprehensive Church organization adapted to the country. While the community as a whole, as may be expected from its origin and history, cannot be said to have shown any strong and widespread desire in this direction, neither can it be said that there is anything within the community itself which would militate against the realization of such an ideal. This Conference, therefore, considers that every facility should be afforded for the spread and development of this desire in the Indian Christian community at large.'

Such are some of the ideals regarding co-operative action which found expression in the various findings. But each conference ere it disbanded had to decide a question of great importance. Was there to be any body specially charged with the duty of working for the realization of these ideals? The hesitation with which many faced this question may well be understood. The number of committees and conferences is already considerable, and the feeling is often expressed that the time spent in connexion with them might be better employed in attending to ordinary duties. A number of these organizations, too, exist for the purpose of co-operative effort, and the need of any new body might be questioned. Yet each of the provincial conferences, facing the problem in the light of the needs of its own area, decided that there must henceforth be some representative council which would stand for the principle of united action and endeavour to promote it wherever practicable. Existing missionary associations might possibly be adapted to serve this purpose, if only they could become representative of missions as missions. While it was clearly realized everywhere that such councils 
could only be advisory, yet it was felt to be essential that they should be so constituted as to secure that their advice would carry considerable weight, and with this in view the plan which found most acceptance was to have the councils as far as possible elected by the bodies at work in the area, care being taken to secure by means of co-option that no important interest was neglected. At the national conference the outline of a constitution for such provincial councils was drawn up and recommended as a guide, but no attempt at rigid uniformity was contemplated, and the actual constitution of each council will vary according to the prevailing opinion as to the needs of the area.

Now came a further important question: Were these provincial councils to be left in isolation, or had the time come for the formation of a national council, which might stand to the provincial councils somewhat in the same relation as these did to the missions? That the provincial councils by themselves might do much was not questioned. They might, too, communicate as occasion required with one another, and stand in close relation to the Continuation Committee, being thus kept in touch with the home base and with other parts of the mission field. Their formation was already a distinct step in advance : was it clear that the time had come for this further step? India was large, and considerable expenditure of time and money would be necessary if a national council was to be more than a name. It can hardly be wondered at that such thoughts were in the minds of many who gathered in Calcutta. Yet by the time the Committee on Co-operation was ready to bring forward a definite proposal for the formation of a national council it was obvious that a change was taking place, and that those who had begun by counting the cost had become ready for a daring venture. So it came about that the committee's scheme was adopted without any questioning of its main principles, and with only a few modifications in detail. The report of the committee as a whole was adopted by a standing vote, and then a member who had 
in past years done noble service in the cause of union led the Conference in a prayer of thanksgiving.

\section{The finding regarding a national council is as follows :}

National CounciL. -With a view to co-ordinating the activities of the Provincial Councils the Conference resolves to take steps for the formation of a National Council in accordance with the following plan :

a. Name :-

The Council shall be called the National Missionary Council of India.

b. Objects :-

The objects of the Council shall be-

(1) To co-operate with the Provincial Councils in the carrying out of their objects.

(2) To be in communication with the Continuation Committee of the Edinburgh Missionary Conference regarding such matters as require consideration or action from the point of view of the Indian mission field as a whole.

(3) To take into consideration such other questions affecting the entire missionary field as may seem to it desirable.

(4) To make provision for the convening of an All-India Missionary Conference when such is in the opinion of the Council-desirable.

c. Methods :-

In furtherance of the above objects the Council shall-

(1) Hold an annual meeting.

(2) Consider all matters referred to it by any Provincial Council and take such action as it may deem best.

(3) Receive and consider the annual reports of the said Councils.

(4) Appoint from its own membership or otherwise occasional or standing committees to deal with subjects demanding special consideration.

(5) Appoint an Executive, which shall ordinarily meet midway in time between the annual meetings of the Council for the consideration of matters referred to it by the Council and such other matters as may seem to require immediate attention, the decision of the Executive in the case of the latter to be presented to the Council for ratification by correspondence.

d. Constitution :-

(1) The membership of the Council shall be constituted as follows : Two members elected by each of the following Provincial Councils : (i) Madras, (ii) Bombay, (iii) Central Provinces and Central India, (iv) The United Provinces, (v) The Punjab and Rajputana, (vi) North-East India and (vii) Burma; and members co-opted by the elected members to bring the total membership up to twenty-four. 
(2) Members shall be elected to serve for a period of three years, one-third retiring by rotation each year.

Note 1.-The provincial areas shall be understood to be those on the basis of which the recent Continuation Committee Conferences have been held, subject to such re-arrangement as may be suggested by the National Council or may be mutually agreed upon.

Note 2.-The functions of the Council shall be solely consultative and advisory and not legislative or mandatory.

Note 3.-The above is submitted as a draft scheme for the tormation of the Council, but is subject to such amplification or modification by the Council itself as experience may suggest or need require.

Note 4.- The formation of the Council shall be entrusted to an Interim Committee to be appointed by this Conference.

Having taken the necessary steps to bring this organization into being, the national conference felt that it might well leave to it and to the provincial councils the formulation of principles of comity and schemes for co-operation. It was thought best, however, to reaffirm certain great principles which experience has shown to be of the highest value, and to express certain desires for their fuller application. Among these was one which many have felt to be necessary though it has seldom found formal expression. The consideration of the matter was suggested by one of the questions proposed for discussion at the provincial conferences: 'Does satisfactory provision exist for the proper correlation of missionary activities (1) between missionaries in a given station; (2) between different phases of work in the same mission?' This led to searching of heart in some quarters. In the paper on co-operation presented to one of the conferences the following passage occurs : 'Even if the personal relations of missionary colleagues were all that could be desired (and is it so in all cases ?) it might happen that great loss was being incurred through the fact that each went his own way regardless of the others, or that a missionary did less than might be done to bring the different departments of his own work into relation to each other. School work, for instance, would be more likely to lead to definite results if it were followed up by zenana visiting in the case of women and preaching in 
the case of men.' Obvious as this may seem, it was admitted in more than one conference that attention required to be called to it, and at the national conference the following finding was reached: "That the importance be urged on each mission within the area of paying attention in their own activities to the proper correlation of the various forms of missionary work.'

The finding of the national conference regarding the desire for a national Church has already been quoted, but the matter was not allowed to rest there. In view of the prevailing diversity of view in church matters no attempt was made to say what the next practical step should be, or to decide which of the possible forms of union was preferable. Yet if prayer be the most practical thing in life it may be evident ere long that the conference took a very practical step indeed in passing the following resolution :

'In Conclusion, this conference, feeling certain that the unity of Christendom is in accordance with the divine purpose and is the means by which, above all else, the world will be brought to recognize in our Lord Jesus Christ their Saviour and Redeemer, and thankfully recognizing the many evidences that at the present time this truth is being brought home to the hearts and consciences of Christians all over the world by the manifest working of the Holy Spirit of peace and love, most earnestly calls upon all to whom its voice may come to be instant in believing prayer to the God and Father of our Lord Jesus Christ that He will vouchsafe speedily to accomplish His gracious purpose and hasten the day when the prayer of our Redeemer may be fulfilled and all $\mathrm{His}$ people be perfected into one.'

If the whole problem is faced in this spirit we may look forward to such developments as will make talk about a new era less of an exaggeration than it seemed at first. The difficulties to be faced are of course enormous. Many who had not the advantage of attending the conferences can hardly be blamed if they look coldly on the organization which is being created, and smile at the enthusiasm of those who helped to bring it into being. Yet there is good reason to believe that in this case the enthusiasts are right. They have to encourage them not only the con19 
siderations stated at the beginning of this paper, but certain others which may be mentioned at its close. Had a proposal for a national council been made a few years ago it would probably have been condemned as chimerical, and if it had come into existence it is doubtful if it would have accomplished much. The time was not ripe. But the need of co-operation is increasingly felt, and the experiments made in the way of joint effort and even of church union have been, on the whole, remarkably encouraging. A change, too, is taking place in the spirit of the time, and large numbers are filled with a new eagerness to transcend those barriers which diversity in doctrine or polity or practice has raised. Of this spirit the Edinburgh Conference was the most notable expression, and it in turn has done immeasurable service in fostering it and securing its spread throughout the world. The influence of 'Edinburgh, 1910' was already felt in India. It was accordingly at an opportune time that the series of Indian conferences was held. Is it not obvious that the hand of God is in it all ? Such at any rate is the conviction of the men and women who had the privilege of facing the great task together, and they have gone back to their ordinary spheres of labour with a determination not to rest till their fellow-workers see something of that vision which opened up before their eyes in those memorable days, and join them in strenuous effort for its realization.

J. H. Maclean 